\title{
The scid gene encodes a trans-acting factor that mediates the rejoining event of Ig gene rearrangement
}

\author{
Eric A. Hendrickson, ${ }^{1,2}$ David G. Schatz, ${ }^{3,4}$ and David T. Weaver ${ }^{1,2,5}$ \\ ${ }^{1}$ Division of Tumor Immunology, Dana-Farber Cancer Institute, and ${ }^{2}$ Department of Microbiology and Molecular Genetics, \\ Harvard Medical School, Boston, Massachusetts 02115 USA; ${ }^{3}$ Whitehead Institute for Biomedical Research, and ${ }^{4}$ Department \\ of Biology, Massachusetts Institute of Technology, Cambridge, Massachusetts 02139 USA
}

Homozygous mutation at the scid locus in the mouse impairs lymphoid development and results in animals deficient in $B$ and $T$ cells. We found that immunoglobulin heavy-chain gene rearrangement was blocked at the $D-J_{H}$ stage in Abelson-transformed scid pre-B cell lines. Examination of the recombinational junctions indicated that the correct gene elements $\left(D\right.$ and $\left.J_{H}\right)$ were assembled, as shown by the presence of $D$ region and $J_{\mathrm{H}^{-}}$-region DNA on the breakpoint restriction fragments cloned from the genome of the scid cell lines. All rearrangement events were accompanied by deletions of varying sizes such that none of the rearrangements resulted in the production of functional immunoglobulins. The breakpoints of the rearrangement events did not correspond to the utilization of a novel heptamer-nonamer recombination signal but probably arose by nonspecific deletion from distal $J_{\mathrm{H}}$ and $D$ heptamer-nonamer signals in the process of recombination. scid pre-B cell lines were infected with a recombinant retrovirus (DGR) containing Ig joining signals. Aberrant rearrangements were observed in DGR DNA that was integrated randomly throughout the mouse genome, which suggested that the mutation in scid mice encodes a trans-acting factor that is part of the lymphoid gene recombination machinery.

[Key Words: scid; immunodeficiency; immunoglobulin gene rearrangements; lymphoid development]

Received March 3, 1988; revised version accepted May 9, 1988.

DNA rearrangement of lymphoid genes is restricted in differentiation to the early stages of B- and T-cell maturation. The recombination events that join variable region gene segments $\langle V, D$, and $I)$ of any of the immunoglobulin (Ig) or T-cell receptor (TCR) gene families occur in distinct tissue-specific and temporal patterns (Alt et al. 1986; Kronenberg et al. 1986). In the mouse, $D-I_{H}$ joining always precedes $V-D I_{H}$ joining in Ig heavy-chain gene rearrangement (Alt et al. 1984). Two lines of evidence suggest that an enzymatic activity $[V|D| /$ recombinase] mediates all the lymphoid gene rearrangement events: (1) Conserved cis-acting heptamer-nonamer DNA sequences flank the variable region gene segments of all the gene segment families (Early et al. 1980; Sakano et al. 1981; Tonegawa 1983; Davis 1985), and (2) exogenous TCR or Ig recombination signals can stimulate DNA rearrangement when introduced into pre-B cell lines (Blackwell and Alt 1984; Lewis et al. 1984, 1985; Yancoupoulos et al. 1986). Other proteins or factors are presumed to modulate the activity of the $V|D| J$ recombinase at subsequent rearrangement steps. With the exception of terminal deoxynucleotidyl transferase (TdT), implicated in $\mathrm{N}$-region formation (Alt and

\footnotetext{
${ }^{5}$ Corresponding author.
}

Baltimore 1982; Desiderio et al. 1984; Landau et al. 1987), none of the enzyme activities responsible for Ig and TCR gene recombination have been identified.

Homozygous mutation of the scid locus in the mouse disrupts both B- and T-cell lymphoid development, resulting in immeasurable or low serum immunoglobulin levels, the absence of cells bearing $\mathrm{T}$ - or B-cell determinants, and lack of functional $\mathrm{T}$ cells as assayed by skin allograft rejection (Bosma et al. 1983). The scid defect specifically affects the lymphoid subset of the hematopoietic lineages because myeloid and erythroid differentiation are normal (Dorschkind et al. 1984). Aberrant rearrangement of Ig and TCR genes have been found in scid Abelson murine leukemia virus (Ab-MLV)-transformed bone marrow cells and spontaneous thymic lymphomas (Schuler et al. 1986). In these cells, Ig heavychain gene rearrangements and TCR $\beta$-gene rearrangements were accompanied by a high incidence of deletions that removed all or part of the $J_{H}$ region and the I $\beta 2$ locus, respectively. These data suggested that the scid mutation altered some component of the recombination system common to both lineages (Schuler et al. 1986).

We would like to understand where the scid mutation acts in lymphoid differentiation and what process in the 
DNA rearrangement of lymphoid genes is disrupted. In this paper we show that the first rearrangement events of pre-B cells $\left(D_{H}-J_{H}\right)$ are defective in scid mice. Cloned restriction fragments from the $I_{H}$ region demonstrated that the breakpoint junctions were generated by joining $D$-element regions to the $I_{H}$ region, as is observed for wild-type cells. However, although the appropriate $I_{H}$ and $D_{H}$ chromosomal regions were selected, no scid $D_{H}-I_{H}$ rearrangement was compatible with the synthesis of an Ig gene product. The precise junctions of nine independent breakpoints were characterized: None flanked consensus DNA sequences that resembled, in any way, the conventional heptamer-nonamer recombination signals. The breakpoint sequences appear to have arisen by nonspecific deletions originating from the $I_{H}$ and $D_{H}$ signal sequences during the process of recombination. In scid cell lines with an integrated copy of a recombinant retrovirus containing Ig rearrangement heptamer-nonamer sequences, subsequent rearrangements of these sequences also produced nonspecific deletions. These data suggest that the scid gene encodes a trans-acting factor involved in lymphoid gene rearrangement that acts at the joining stage of the recombination mechanism.

\section{Results \\ scid pre-B cell lines have faulty Ig heavy-chain rearrangements}

Pre-B cells from the bone marrow of a scid homozygous mouse were transformed with Ab-MLV (Rosenberg and Baltimore 1976, Weaver et al. 1985), and 12 independent pre-B-cell lines were established. Genomic DNA isolated from these cell lines was digested with $E c o R I$ and analyzed by Southern blots to detect DNA rearrangements in the $J_{\mathrm{H}}$ region by using a hybridization probe from the $3^{\prime}$-side of the $J_{\mathrm{H}}$ region (Fig. 1). In wild-type pre-B-cell lines transformed by Ab-MLV, both alleles normally have undergone Ig heavy-chain $D /_{\mathrm{H}}$ or $V_{\mathrm{H}} D /_{\mathrm{H}}$ rearrangements, resulting in new EcoRI sites flanking the $J_{H}$ region (see Fig. 2) and thus generating two new hybridizing bands. When we tested the scid cell line DNAs by this protocol, the Ig rearrangement state of the two alleles fell into three classes: $(1)$ no hybridizing bands: $3 \mathrm{C}$; $(2)$ only one hybridizing band: $7 \mathrm{~B}, 2 \mathrm{~B}, 3 \mathrm{D}, 8 \mathrm{E}$, $8 \mathrm{~B}, 8 \mathrm{D}$, and $6 \mathrm{~A}$; and $(3)$ two hybridizing bands: $2 \mathrm{~A}, \mathrm{~A}$, $\mathrm{A} 2$, and $7 \mathrm{~A}$ (Fig. 1). By comparison to unrearranged nonlymphoid DNA from wild-type mice (BL6, Fig. 1), all the hybridizing bands in the scid cell lines were from rearranged alleles. Cell lines with either one or no hybridizing bands presumably deleted the region complementary to the 3 '-probe on one or both alleles, respectively. The scid cell lines with two hybridizing bands may have undergone wild-type rearrangement events or may have undergone aberrant events in which the region homologous to the probe simply was retained. These data supported an interpretation similar to that of Schuler et al. (1986), who postulated that the scid mutation disrupted normal Ig gene rearrangement. We examined rearrange- ment of the Ig $\kappa$ light-chain genes by Southern blot analysis with a $J_{\kappa}$ hybridization probe (Weaver et al. 1985), but no indication of loss of alleles or $\mathrm{k}$ rearrangements in any of the scid cell lines was found (data not shown). Most wild-type Ab-MLV cell lines lack light-chain rearrangements, suggesting that they are transformed during the process of Ig heavy-chain rearrangement. Thus, the rearrangement status of the scid cell lines indicated that they were transformed at a time in differentiation similar to that of wild-type pre-B cells.

We determined the nature of the rearrangement defect in the scid cell lines by complete characterization of several of the rearrangement events. The EcoRI fragments containing the Ig heavy-chain rearrangement breakpoints from nine independent scid rearrangements were cloned, utilizing the same hybridization probe $\left(3^{\prime}\right.$-probe, Figs. 1 and 2) and size-selected phage $\lambda$ gt10 libraries from the scid cell lines (see Experimental procedures). The $E c o$ RI breakpoint fragments from the $J_{\mathrm{H}}$ cluster sub-
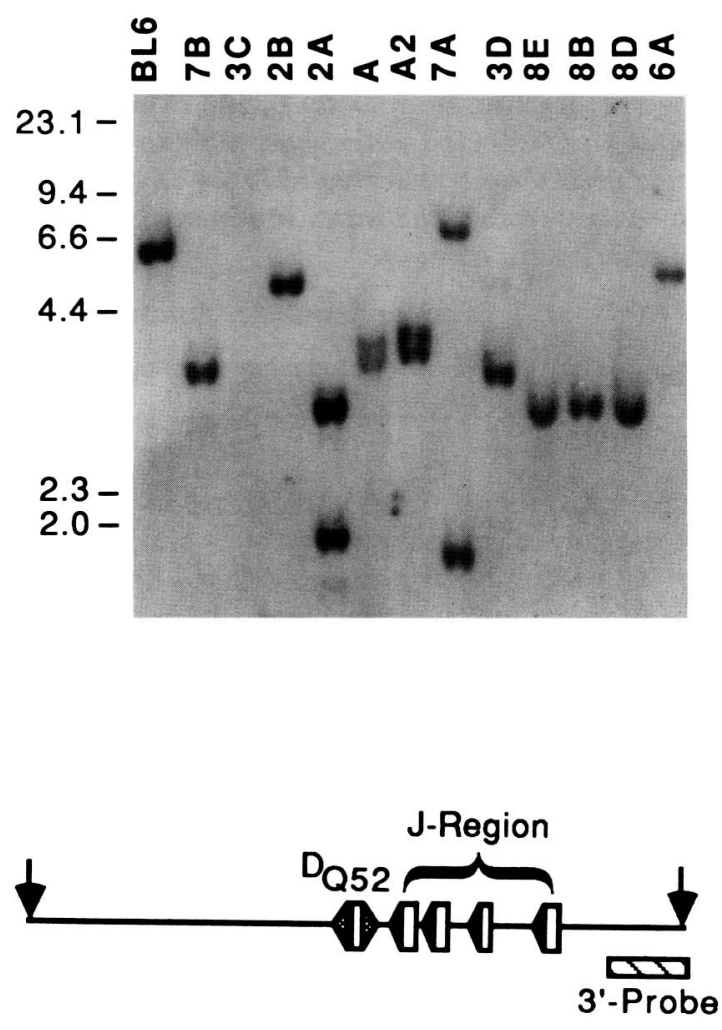

Figure 1. DNA rearrangement in the $J_{\mathrm{H}}$ region in scid pre-B cell lines. (Top) Genomic DNA was isolated from 10 independently-derived Ab-MLV scid cell lines (7B-6A), digested with $E c o$ RI, and fractionated on an $0.8 \%$ agarose gel for Southern blot analysis. C57BL6 liver DNA (BL6) shows the 6.4-kb unrearranged EcoRI fragment of the $/_{\mathrm{H}}$ region. A $0.7-\mathrm{kb} \mathrm{XbaI}-$ EcoRI fragment ( 3 ' probe) was used as the hybridization probe. (Bottom) The 6.4-kb germ-line EcoRI fragment containing the Ig $I_{\mathrm{H}}$ region. (Arrows), EcoRI sites; (triangles), heptamer-nonamer recombination signals flanking the $D$ and $J_{\mathrm{H}}$ gene segments (open rectangles). 


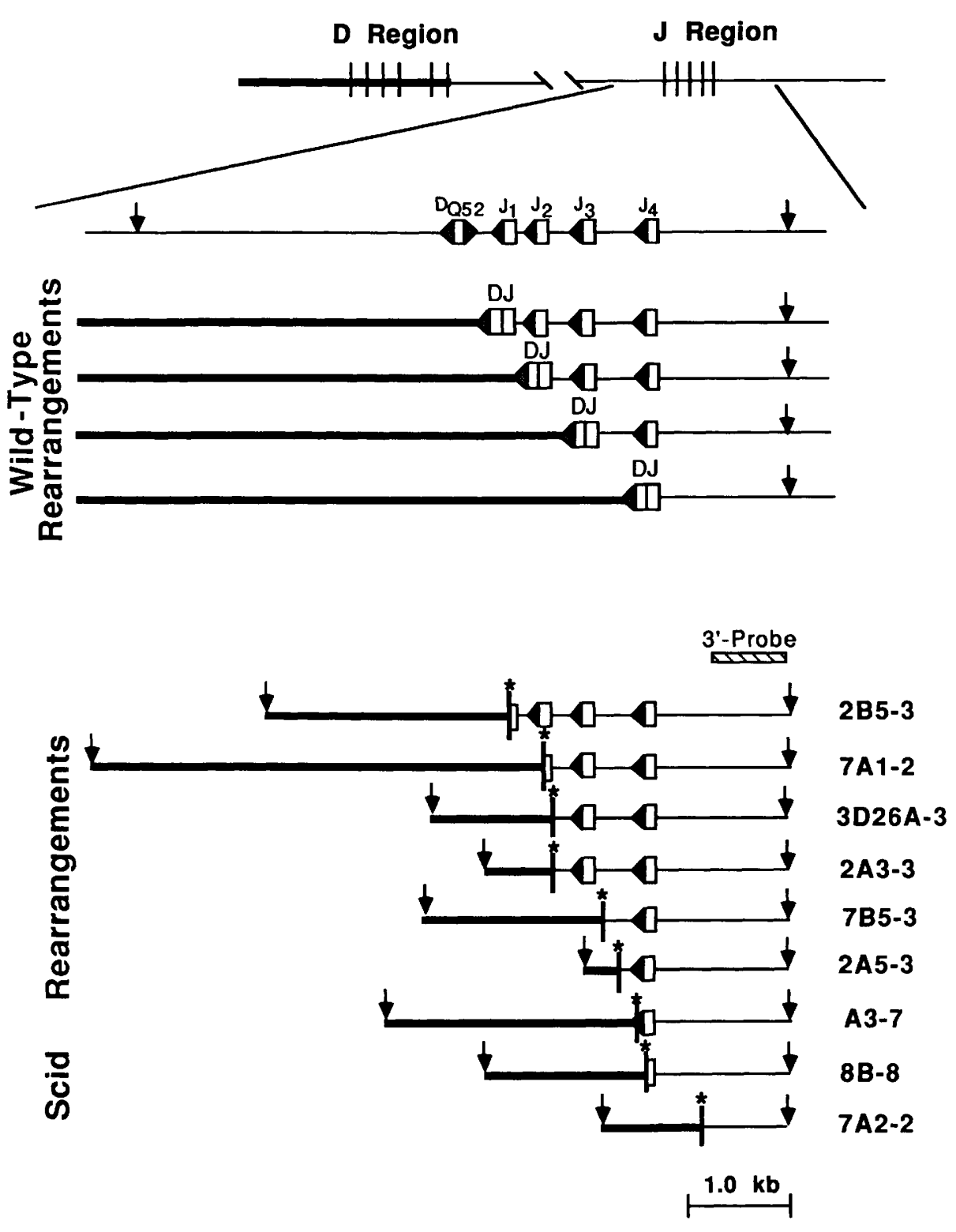

Figure 2. scid rearrangements in the $J_{\mathrm{H}}$ region are defective. (Top) Wild-type $D-J_{\mathrm{H}}$ rearrangements occur by the joining of a $D$ element from the $D$ region to one of the four $J_{\mathrm{H}}$ elements. These rearrangements are characterized by the generation of novel EcoRI fragments hybridizing to the $3^{\prime}$ probe and breakpoints that occur at the junction of the $D$ and $/$ elements mediated by the heptamernonamer recombination sequences (triangles). (Bottom) The EcoRI fragments cloned from the $J_{H}$ region of nine independent rearrangements in scid pre-B cell lines. Designations in the right column refer to the scid Ab-MLV cell line of Fig. 1 from which the breakpoint fragment originated. The numbers following the cell line designation only refer to individual isolates derived from the $\lambda$ phage DNA libraries for each scid cell line. The thick horizontal line represents DNA from the $D$ region, with the exception of the $D_{\mathrm{Q} 52}$ element. $\left({ }^{*}\right)$ The breakpoint junction.

sequently were subcloned into pUC19 (Fig. 2). Restriction enzyme analysis showed that each of the clones differed from the germ-line 6.4-kb EcoRI fragment in their 5 '-regions (data not shown). The point at which the scid $J_{\mathrm{H}}$-region DNA diverged from the known J-region sequence was localized to within $100 \mathrm{bp}$, using fine-scale restriction mapping. The DNA sequences of the nine breakpoint-containing regions were determined (Experimental procedures|. In normal Ig rearrangment, 1 of $\sim 12$
$D_{H}$ elements, located over $20-90 \mathrm{~kb} 5^{\prime}$ to the $J$ region (Kurosawa and Tonegawa 1982), is joined to one of the 4 $J_{\mathrm{H}}$ elements, placing the breakpoint at the $5^{\prime}$-border of one of the four $J_{\mathrm{H}}$ elements (wild type, Fig. 2). In all cases of the scid rearrangements, the location of the breakpoints demonstrated that each joining event was defective (scid, Fig. 2). Even in two cases of scid cell lines where two rearranged $J_{\mathrm{H}}$ alleles were observed with the 3 '-probe (7A and $2 \mathrm{~A}$ in Fig. 1), the rearrangements char- 
acterized for both alleles were abnormal $(7 \mathrm{~A} 1-2$ and 7A2-2; $2 A 3-3$ and 2A5-3). Thus, scid pre-B cell lines could not generate precise functional $D /_{\mathrm{H}}$ or $V D /_{\mathrm{H}}$ rearrangement events.

\section{Aberrant scid $\mathrm{D}-\mathrm{J}_{H}$ rearrangements are produced}

We tested whether the scid rearrangements that occurred in the $I_{\mathrm{H}}$ cluster were the result of attempted $D_{H}-J_{\mathrm{H}}$ joining, which ordinarily occurs at the pre-B cell stage by probing the scid breakpoint clones for D-element homology using the relatively conserved $5^{\prime}$ flanking DNA sequences of Ig $D_{\mathrm{H}}$ elements (Kurosawa and Tonegawa 1982; Alt et al. 1984). Sequences in the immediate 5'-flanking region of the $D_{\mathrm{FL} 16}, D_{\mathrm{SP} 2}$, and $D_{\mathrm{Q} 52}$ families hybridize to other members of the same family and exhibit substantial cross-hybridization to members of the other two families. A SacI-BgIII fragment $\left(' D^{\prime}\right.$ probe), located $\sim 500 \mathrm{bp}$ from the $5^{\prime}$-end of the $D_{\mathrm{SP} 2.7}$ element isolated from p40E4-2-5.2 (Desiderio et al. 1984), was used as a hybridization probe for a Southern blot of the scid EcoRI breakpoint restriction fragments (Fig. 3). As controls, the parent plasmid (p40E4-2-5.2) and a plasmid containing the 5 -flanking sequences of a $D_{\mathrm{FL} 16}$ element (p38B9; Alt and Baltimore 1982) were included. As expected, the $D$ probe hybridized to the parent plasmid from which it was derived and cross-hybridized to the $D_{\mathrm{FL} 16}$ plasmid (Fig. 3A, lanes 1 and 2). In addition, two of the scid clones, A3-7 and 7A1-2, showed strong homology to the $D$ probe (lanes 3 and 6). An identical Southern blot probed with the 5 '-flanking sequence of the $D_{\mathrm{FL} 16.1}$ element from p38B9 hybridized only to the same two scid clones (data not shown). We localized the region of homology to the $D$ probe in clone $7 \mathrm{Al}-2$ to a 1.3-kb PstI fragment by additional Southern blotting (Fig. 3B, top). However, because the $D$ probe homology was located only $\sim 200 \mathrm{bp}$ away from the breakpoint, we presumed that the flanking $D$ element had been deleted during rearrangement. In clone A3-7, the region of $D$ homology was also localized near the breakpoint. A previously uncharacterized $D$ element (named $D_{\mathrm{SP} 2.10}$ ) was identified only $51 \mathrm{bp}, 5^{\prime}$ of the breakpoint, by DNA se-

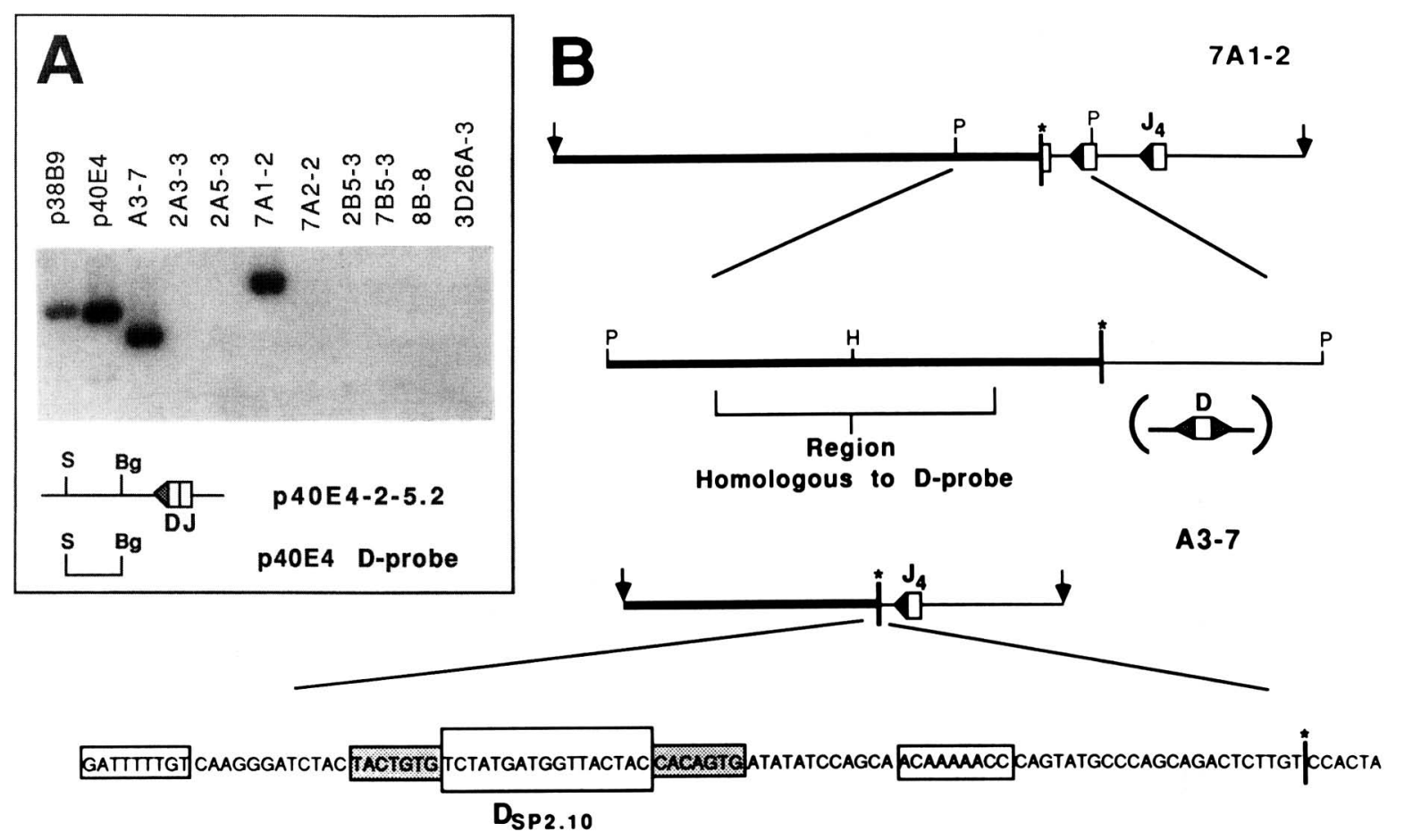

Figure 3. DNA rearranged into the $I_{\mathrm{H}}$ cluster contains $D$ elements. $|A|$ Southern blot of the scid breakpoint-containing plasmids digested with EcoRI and probed with $D$-region DNA sequences. The hybridization probe (p40E4) was the 0.5-kb SacI-BglII fragment from the $5^{\prime}$-flanking region of a $D$ element in the plasmid p40E4-2-5.2. p38B9 and p40E4 are plasmids containing $D J_{\mathrm{H}}$ rearrangements and $D_{\mathrm{FL} 16}$ and $D_{\mathrm{SP} 2}$ elements, respectively (Alt and Baltimore 1982; Desiderio et al. 1984). (B) The 6.8-kb EcoRI fragment, 7Al-2, that hybridized to the $D$ probe is shown. By an additional Southern blot, the $D$ probe homology was localized to the $1.3-\mathrm{kb} P$ stI fragment spanning the breakpoint. This homology region was split by digestion with HincII, located 400 bp upstream of the breakpoint (data not shown). Because the region of homology for the $D$ probe was so close to the breakpoint, the flanking $D$ element for $7 \mathrm{~A} 1-2$ was presumably within $200 \mathrm{bp}$ of the breakpoint position. The $4.0-\mathrm{kb}$ EcoRI fragment, A3-7, that hybridized to the $D$ probe is shown. By DNA sequencing, a previously uncharacterized $D$ element was localized $51 \mathrm{bp}$ from the scid breakpoint. The nonamer and heptamer sequences are boxed flanking the $D_{\mathrm{SP} 2.10}$ element. (*) The position of the breakpoint. (S) SacI; $(\mathrm{Bg})$ BglII; $(\mathrm{P})$ Pst $;$ (H) HincII; (arrows), EcoRI. 
quencing (Fig. 3B, bottom). $D_{\mathrm{SP} 2.10}$ appears to be a member of the $D_{\mathrm{SP} 2}$ family, differing by only 2 or $3 \mathrm{nu}$ cleotides from other family members (Kurosawa and Tonegawa 1982). $D_{\mathrm{SP} 2.10}$ contains the canonical heptamer-nonamer sequences necessary for recombination and, by this criteria, is fully functional for rearrangement; however, $D_{\mathrm{SP} 2.10}$ was probably not the element used in the rearrangement event that produced clone A3-7, because its $3^{\prime}$ heptamer-nonamer sequences were completely intact. It is more likely that a $D$ element $3^{\prime}$ to $D_{\mathrm{SP2} \text {.10 }}$ was used in the rearrangement but was then subsequently deleted such that the juxtaposition of $D_{\text {SP2.10 }}$ with the breakpoint was coincidental. These data strongly suggested that DNA from the $D_{\mathbf{H}}$ region was used in the recombination events that generated clones 7A1-2 and A3-7. The other scid cell lines may also contain DNA from the $D_{\mathrm{H}}$ region in the breakpoint fragments but may have deleted the DNA sequences that cross-hybridize to the $D$ probe.
To address this question further, we utilized a second assay to identify the chromosomal origin of the novel DNA sequences in the $5^{\prime}$-flanking region of the breakpoint-containing fragments. Genomic DNAs were prepared from mouse liver DNA and BAF3-12 cell lines (germ-line Ig configuration), four wild-type Ab-MLV pre-B cell lines containing normal $D /_{\mathrm{H}}$ rearrangements on both alleles $(D I)$, and five wild-type Ab-MLV pre-B cell lines containing normal $V D J_{\mathrm{H}}$ rearrangements on both alleles (VDI, Fig. 4A), where the Ig rearrangement status of these lines had been documented previously (Alt et al. 1984). The $V D /_{\mathrm{H}}$ rearranged cell lines have deleted the entire $D_{\mathrm{H}}$ region (except for the 10-20 bp that constitute the $D$ element) as a consequence of normal heavy-chain rearrangement. The $D /_{H}$ rearranged cell lines have deleted some, all, or none of the $D_{\mathrm{H}}$ region DNA, depending on the position of the $D$ elements participating in DNA rearrangement. Hybridization probes were prepared from small restriction fragments of four

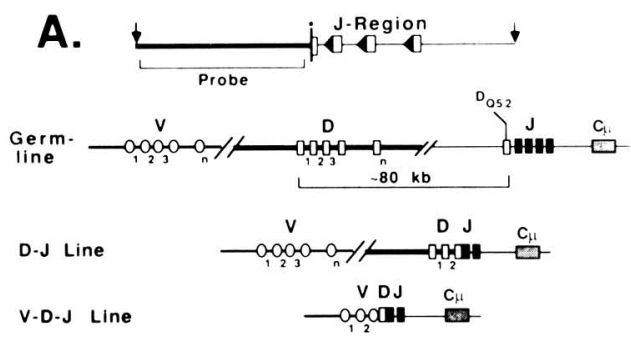

B.

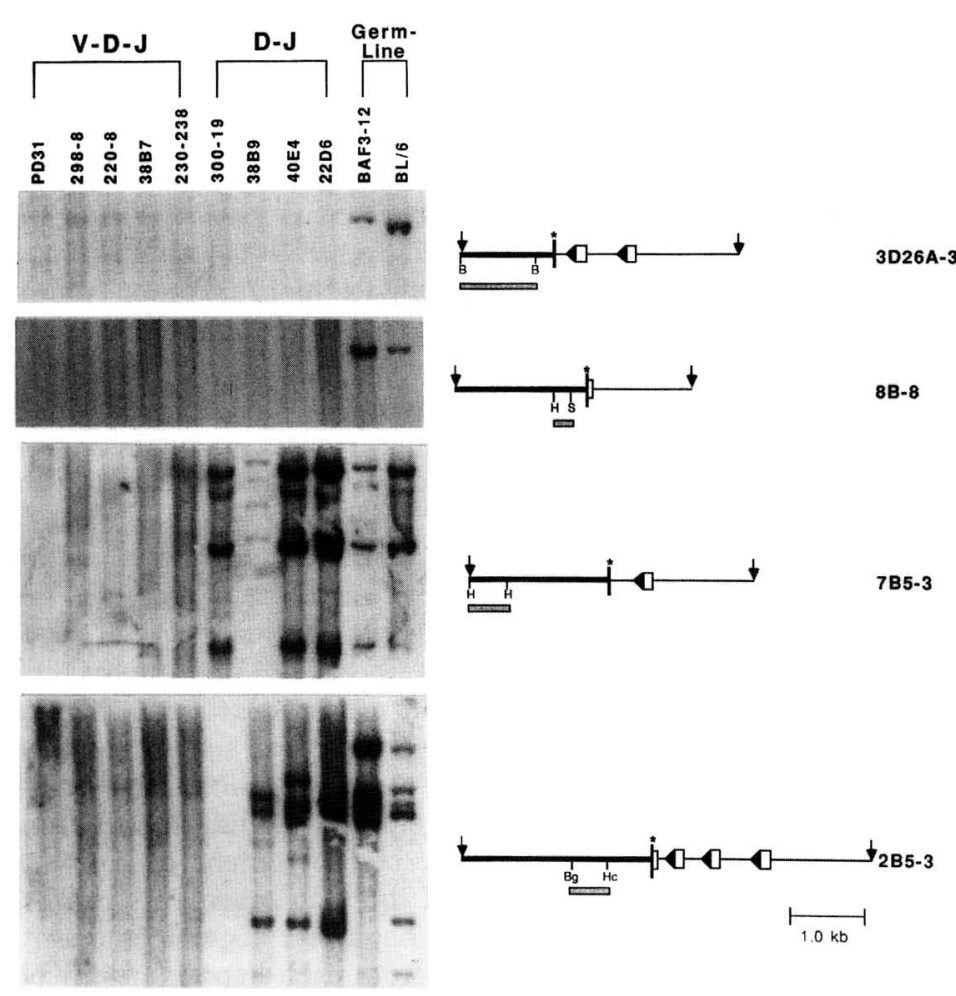

Figure 4. DNA rearranged into the $/_{\mathrm{H}}$ cluster originates from the $D$ region. $(A)$ Determination of the chromosomal region of origin of DNA joined to the $/_{\mathrm{H}}$ region in scid rearrangements. Ig heavy-chain gene rearrangement proceeds in two stages: the joining of a $D$ to a I element followed by the joining of a $V$ to a $D J$ element. Ab-MLV pre-B cell lines have been isolated with both alleles at $D I$, or with both alleles at $V D I$, as well as other combinations. We have used a set of normal Ab-MLV cell lines with known Ig rearrangement status to specify the origin of the joined DNAs. (See text for a further explanation of the assay.) (B) Southern blot analysis of wildtype Ab-MLV pre-B cell lines probed with scid breakpoint fragment hybridization probes. The four scid clones used (shown on the far right) are 3D26A-3, 1.0-kb BamHI (B) fragment; 8B-8, 150-nucleotide $\operatorname{HindIII}(\mathrm{H})$ ScaI (S) fragment; 7B5-3, 500-nucleotide HindIII (H) fragment; and 2B5-3 500-nucleotide $B g I I I(B g)-H i n c I I(H c)$ fragment. The DNA used in these blots was derived from cell lines described in Experimental procedures and the text and consisted of five VDI lines, four $D I$ lines, and two germ-line samples. 
scid clones, each from the 5 '-region of the breakpoint fragment (Fig. 4B), and used to probe Southern blots containing EcoRI-digested genomic DNA from the set of unrearranged, partially, or completely rearranged wildtype cell lines above. If the normal genomic position of the probe is in the $D_{\mathrm{H}}$ region, this position will be deleted from all cell lines with $V D I_{\mathrm{H}}$ rearrangements and some of the cell lines with $D I_{\mathrm{H}}$ rearrangements. Hybridization probes from scid clones $3 \mathrm{D} 26 \mathrm{~A}-3$ or $8 \mathrm{~B}-8$ hybridized only to DNA from unrearranged cell lines but not to any of the $D I_{\mathrm{H}}$ or $V D /_{\mathrm{H}}$ rearranged cell lines (Fig. 4B, 3D26A-3 and 8B-8). Hybridization probes from clones 7B5-3 or 2B5-3 hybridized to a series of DNA fragments in the $D /_{\mathrm{H}}$ and the germ-line configuration cell lines but did not hybridize to any of the $V D /_{\mathrm{H}}$ rearranged cell lines (Fig. 4B, 7B5-3 and 2B5-3). The multiple bands detected by the $7 \mathrm{~B} 5-3$ and $2 \mathrm{~B} 5-3$ probes presumably resulted from cross-hybridization of the probe with the flanking sequences of other $D$ elements. Three other probes derived from the scid breakpoint fragments of clones A3-7, 2A5-3, and 2A3-3 showed hybridization to germ-line and $D I_{\mathrm{H}}$ but not $V D /_{\mathrm{H}}$, rearranged cell lines /data not shown). These data strongly argue that the rearranged DNA in all of the scid clones originated from positions in the $D_{H}$ region. Thus, in the six scid rearrangements examined in this fashion, legitimate $D-J_{\mathrm{H}}$ joining events were attempted, although the breakpoint junctions derived were aberrant.

\section{Recognition of heptamer-nonamer recombination sequences in scid rearrangements}

Ig and TCR gene rearrangements are promoted by conserved heptamer and nonamer sequences flanking the Ig and TCR gene segments. In Ig $D-I_{\mathrm{H}}$ recombination, the $D$ element is joined to the $J$ element with deletion of the intervening DNA, which contains the heptamer-nonamer signal sequences at its $5^{\prime}$ and $3^{\prime}$ termini (wild-type positions I and II, Fig. 5A). To identify the signal sequences used in recombination, one can determine the breakpoint in the rearranged DNA and then extrapolate back to the flanking DNA sequences of the germ-line configuration (Fig. 5A). The same logic was used to determine whether the aberrant scid rearrangements resulted from the recognition of altered heptamer-nonamer signals located at other positions in the $D$ and $J_{\mathrm{H}}$ regions by the scid recombinational machinery. The DNA sequences flanking the scid breakpoints that were removed by deletional rearrangements in the $J_{\mathrm{H}}$ region were identified by DNA sequencing across the recombination junctions and comparing these sequences to the known $J_{\mathrm{H}}$ region DNA sequence (position I, Fig. 5B). There was no correlation between the DNA sequences found flanking the scid breakpoints and heptamer-nonamer sequences found bordering normal rearrangement breakpoints. Similarly, there was no common heptamerlike or heptamer-nonamer-like DNA sequences or any other consensus DNA sequence among the nine scid rearrangements, either at the breakpoint junctions or within $100 \mathrm{bp} 5^{\prime}$ to the breakpoint in the $J_{\mathrm{H}}$ region exam- ined (data not shown). Thus, the scid defect probably does not cause aberrant rearrangements by allowing the recombinational machinery to recognize altered or variant heptamer-nonamer sequences in the $J_{\mathrm{H}}$ region.

To determine which DNA sequences were deleted from the flanking area of the breakpoint junctions in the $D$ region (position II, Fig. 5A), we cloned the genomic DNA from the $D$-region side of the breakpoint fragments for two scid clones (3D26A-3 and 7B5-3) from a wild-type genomic DNA $\lambda$ phage library (see Experimental procedures). EcoRI fragments derived from the positive phage clones were subcloned into pUC19 |614-4 and $709 \mathrm{~T}-1$, see Fig. 6). By comparing the restriction digestion pattern of 3D26A-3 with scid clone $8 \mathrm{~B}-8$, it was apparent that the $D$-region sequences in 3D26A-3 and 8B-8 were from the same EcoRI restriction fragment, although they contained independent breakpoints. Thus, clone 614-4 allowed the determination of the $D$-region composition both for clones 3D26A-3, from which 614-4 was derived, and for $8 \mathrm{~B}-8$. We localized the rearrangement breakpoints of 3D26A-3, 8B-8, and 7B5-3 by DNA sequencing of 614-4 and 709T-1 and therefore identified the DNA sequences flanking the breakpoint (position II, Fig. 5A) deleted by DNA rearrangement. These DNA sequences bore no resemblance to each other, nor to the heptamer-nonamer recombination sequences occurring at the $3^{\prime}$ side of wild-type $D$ elements (position II, Fig. 5B). Thus, in nine cases at the $3^{\prime}$ side $\left(J_{H}\right)$ and three cases at the $5^{\prime}$ side $\left(D_{\mathrm{H}}\right)$ where scid rearrangement breakpoints were mapped, no consistent DNA sequence features were observed (positions I and II, Fig. 5B). These results indicated that the defect in scid gene rearrangement was not due to the selection of altered recombination sequences, which initiated cleavage and rejoining. Instead, we would argue that scid breakpoints did not coincide with the initial cleavage point for rearrangement but represented the end point of a random deletion event (see Discussion).

The $D$ elements most likely involved in the rearrangement events that generated clones 3D26A-3, 8B-8, and 7B5-3 were identified by DNA sequencing in the genomic regions adjacent to the breakpoint positions. For 3D26A-3 and 8B-8, the $D$ element was identified as $D_{\mathrm{Q} 52}$, which resides only $\sim 700 \mathrm{bp}$ from the $5^{\prime}$ end of the $J_{\mathrm{H}}$ cluster (Fig. 6A). The 614-4 EcoRI fragment obtained from germ-line DNA corresponded to the 6.4-kb EcoRI fragment that also contained the $J_{\mathrm{H}}$ region. The $D$ element within clone 7B5-3 was identified as $D_{\text {FL16.1 }}$ (Fig. $6 \mathrm{~B}$ ), which is located at the $5^{\prime}$-most end of the $D_{\mathrm{H}}$ region (Kurosawa and Tonegawa 1982; Wood and Tonegawa $1983)$. In the three cases examined, the closest $D$ elements lie between 1153 and $1743 \mathrm{bp}$ removed from the breakpoint position. If normal heptamer-nonamer recognition sequences were utilized for both the $D$ and $J_{\mathrm{H}}$ joining step, then in two of these cases, 3D26A-3 and $8 \mathrm{~B}-8$, only the $D_{\mathrm{Q} 52}$ element could possibly have been involved in the gene rearrangement event. It is interesting to note that if the rearrangements initiated concurrently at $J$ and $D$ heptamer sequences, then the extent of deleted DNA from each heptamer may be asym- 

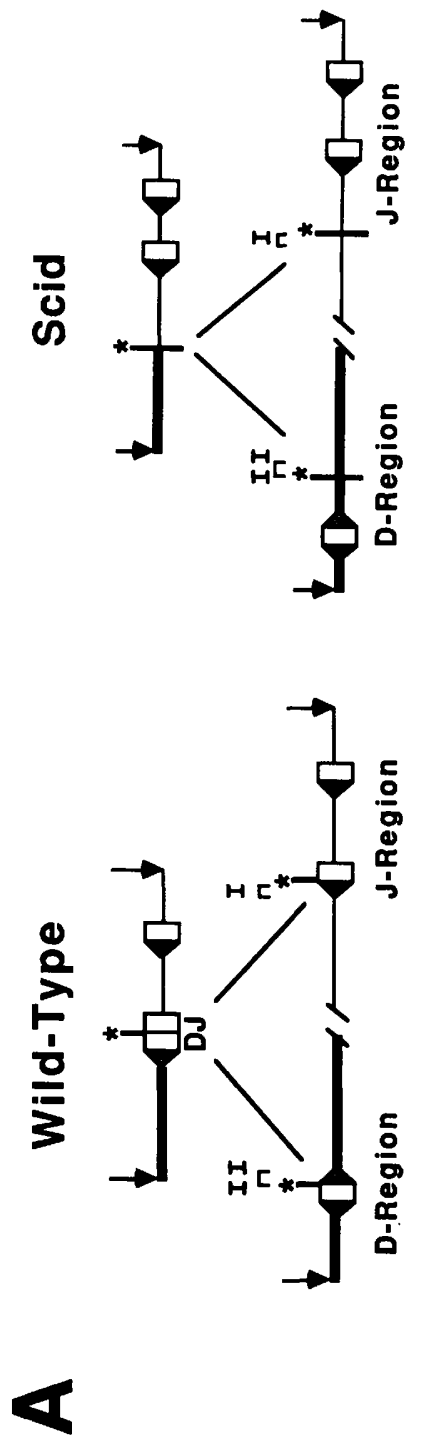

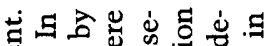

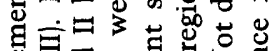

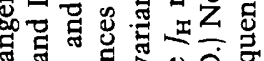

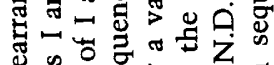

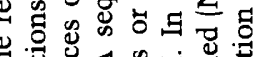

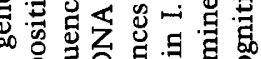

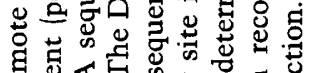

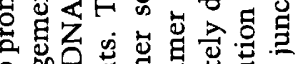

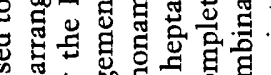

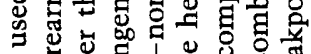

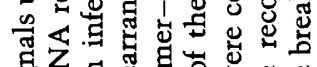

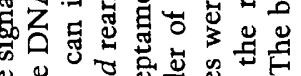

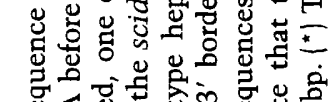

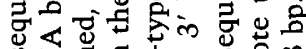

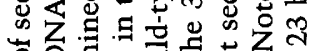

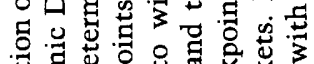

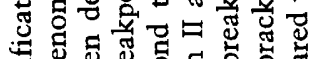

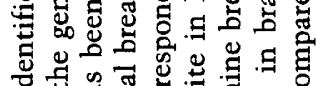

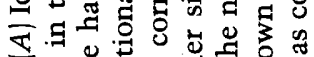

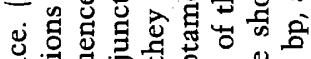

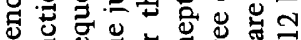

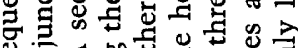

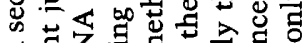

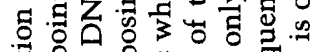

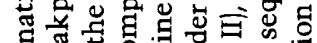

范

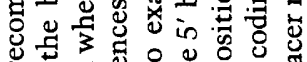

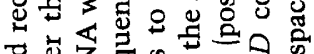

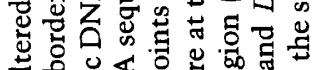

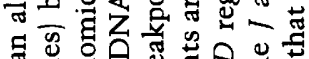

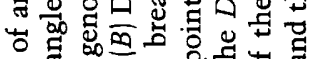

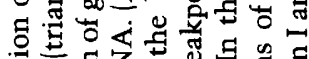

政究包

5o

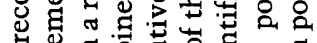

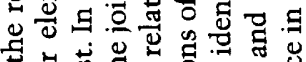

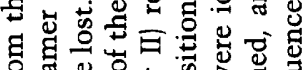

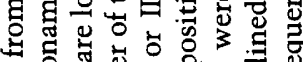

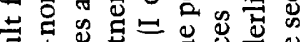

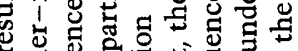

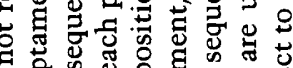

定

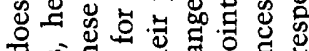

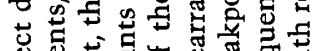

过

0 年

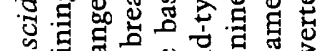

을

$F$ 造

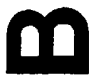

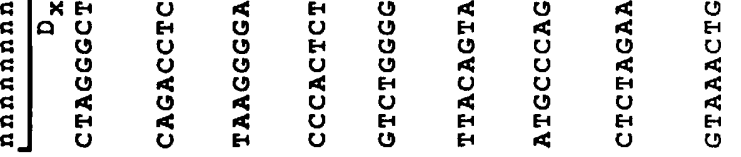

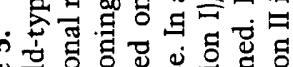

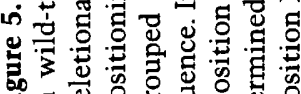


A

3D26A-3

614-4

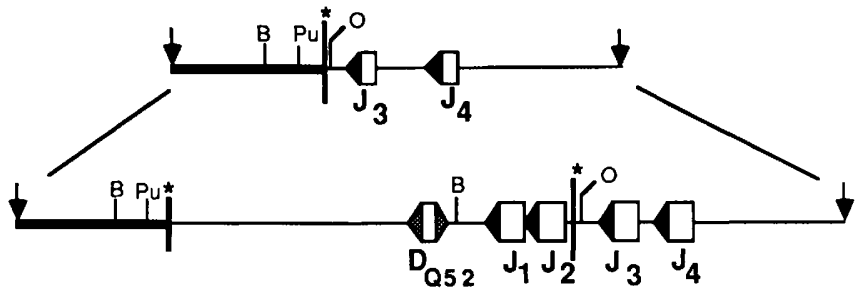

3D26A-3

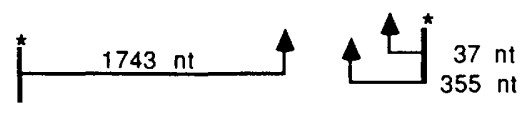

8B-8

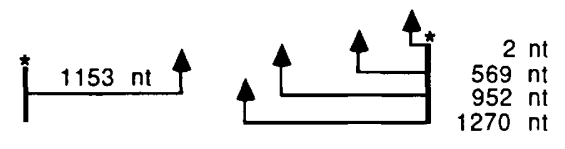

B

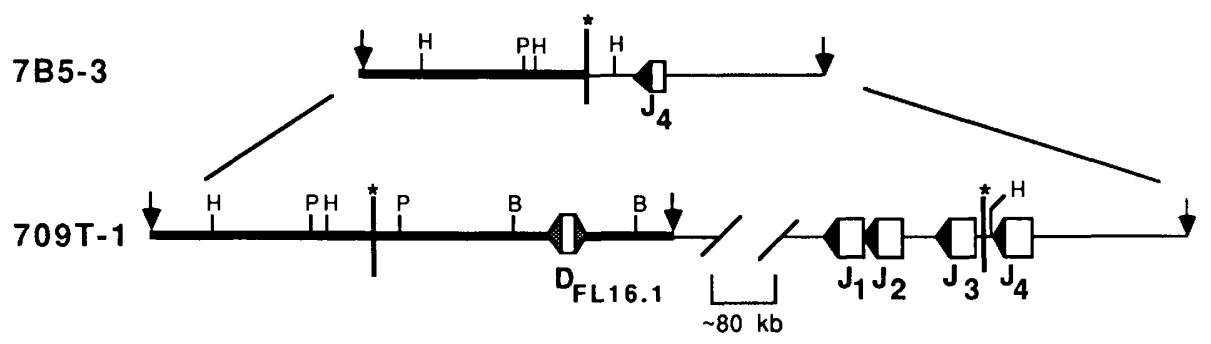

7B5-3

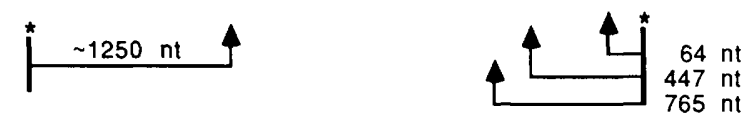

Figure 6. Location of the breakpoint junctions and identification of the $D$ elements associated with three scid rearrangements. $(A)$ scid clone 3D26A-3 is diagramed on the top line. A probe was made from the PvuII (Pu)-OxaNI (O) fragment and used to screen a genomic DNA $\lambda$ EMBL-3 library, as described in Experimental procedures. The resulting EcoRI fragment identified by this screen was subcloned into pUC19 to generate 614-4 (line 2). This EcoRI fragment was the same as the 6.4-kb EcoRI fragment of the $I$ region (see Fig. 1). The BamHI sites used in sequencing the breakpoint junction and the $D$ element are also shown (see Experimental procedures). The distances of the $D$ and $/$ breakpoint junctions from nearby $D$ and $/$ elements for scid clones 3D26A-3 (line 3) and 8B-8 (line 4 ) are shown in nucleotides $(\mathrm{nt}) .(B)$ The same as in $A$, except that clone 7B5-3 and the corresponding genomic $D$-region partner, 709T-1, are shown. Note that clone 709T-1 contains only the EcoRI fragment that encompasses $D_{\mathrm{FL} 16.1}$. (H) HindIII; (P) PstI; (B) Bam HI; (arrows) EcoRI; (*) breakpoint junctions.

metric in the scid cell lines. Clone 3D26A-3 had a deletion more than fivefold greater on the $D$ side (using $D_{\mathrm{Q} 52}$ t than on the $J_{\mathrm{H}}$ side, even assuming the use of the farthest $I$ element from the breakpoint $\left(J_{\mathrm{H} 1}\right.$, Fig. 6A). Clones 7B5-3 and 8B-8 had more or less asymmetry, depending on which $/$ element was utilized.

\section{$\mathrm{N}$ regions in scid rearrangements}

$N$-region insertion occurs frequently at the $D$ and $J_{\mathrm{H}}$ and $V$ and $D I_{\mathrm{H}}$ junctions of Ig gene rearrangement events on endogenous alleles and exogenously added DNA recombination substrates (Alt and Baltimore 1982; Tonegawa 1983; Desiderio et al. 1984; Lewis et al. 1985; Landau et al. 1987). In two of the three scid rearrangement breakpoints (3D26A-3 and 7B5-3) that were completely char- acterized, an ambiguity of 2 and $3 \mathrm{bp}$ in the breakpoints, respectively led to an uncertainty of whether or not any $N$ regions of $1-3$ bp were added. In the case of clone $8 \mathrm{~B}-8$, however, an $N$ region of one nucleotide $(\mathrm{C})$ was found that could not be accounted for by the germ-line DNA sequences of the adjoining $D$ and $J_{\mathrm{H}}$ regions (Fig. 5). The existence of this $N$-region insertion for clone $8 \mathrm{~B}-8$ suggested that the scid defect did not alter TdT function.

\section{The scid gene encodes a trans-acting factor in DNA rearrangement}

The scid mutation may directly affect gene rearrangement or it may disrupt lymphoid cells by an unrelated differentiation process such that the Ig and TCR gene rearrangements are altered adversely. Therefore, we ex- 
amined the persistence of the scid defect in Ab-MLVtransformed pre-B-cell lines to establish the specific role of the mutation in the recombination mechanism. Wildtype Ab-MLV pre-B cell lines generally retain the ability to rearrange exogenous Ig or TCR recombination templates introduced by retroviral infection or transfection (Blackwell and Alt 1984; Lewis et al. 1984, 1985; Akira et al. 1987; Lieber et al. 1987, D. Weaver, unpubl.). scid cell lines (8D and 6B) and wild-type cell lines (38B9 and 230-238) were infected with a recombinant retrovirus, DGR (Landau et al. 1987), that contained a rearrangement cassette consisting of a $V_{\kappa}$ element and two $I_{k}$ elements $\left(J_{\mathrm{a}}\right.$ and $\left.J_{\mathrm{b}}\right)$, the G418 resistance gene neo, and a mycophenolic acid (MPA)-resistance gene, gpt (Fig. 7). G418 resistance selects for cells that integrate the DGR virus but it is independent of whether or not normal $V-I$ rearrangement occurs. MPA resistance selects for cells that have undergone an inversional $V-J$ rearrangement because the transcriptional orientation of the gpt gene in DGR is inverted by rearrangement. The DGR retrovirus integrates via the LTR sequences accurately into chromosomes and has been shown to only rearrange in pre-B cell lines (Landau et al. 1987; Schatz and Baltimore 1988). Therefore, G418-resistant colonies were selected from scid and wild-type cell line infections, and ge-

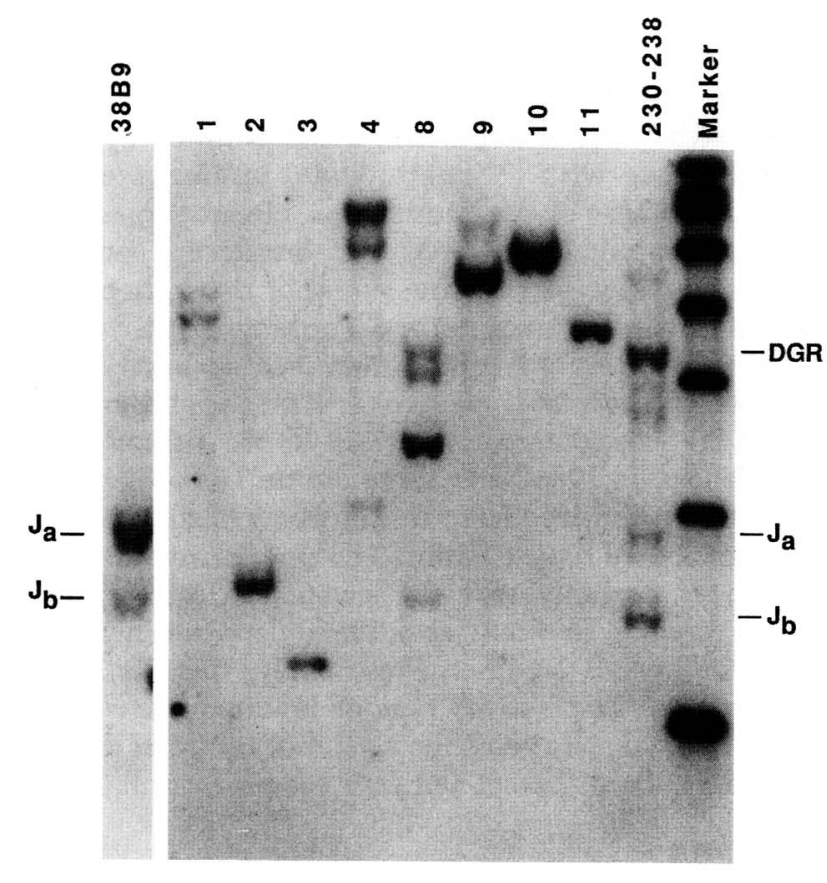

DGR:

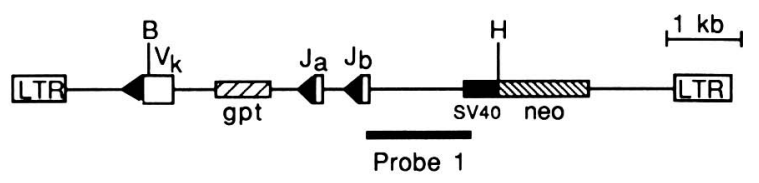

nomic DNA was isolated, digested with BamHI and HindIII, and analyzed by Southern blots using hybridization probe 1 (Fig. 7). The 3.8-kb unrearranged BamHIHindIII DGR fragment is shown in the 230-238 cells (lane 230-238, DGR). $V-J_{\mathrm{a}}$ or $V-J_{\mathrm{b}}$ rearrangement of DGR in this cell line generated primarily two new BamHI-HindIII fragments of 1.9 and $1.5 \mathrm{~kb}\left(J_{\mathrm{a}}\right.$ and $J_{\mathrm{b}}$ respectively, lane 230-238). Additional bands were also detected that presumably arose from secondary rearrangements within the DGR cassette. Secondary rearrangements have been observed previously with DGR and related retroviruses (Lewis et al. 1985; Schatz and Baltimore 1988). An increased frequency of detection of the two primary $V-J$ rearrangements can be selected for in culture with MPA resistance in wild-type cell lines (lane 38B9; see also Landau et al. 1987). In contrast to wild-type rearrangements, all of the G418-resistant scid lines showed strikingly different patterns of hybridization (lanes 1-4, 8-11). These G418-resistant scid cultures were not clonal, and thus several attempted rearrangement events were represented in each cell culture; yet, significantly, none of the rearrangements were the same as wild-type rearrangements. It is interesting to note that these cell lines are generally not resistant to MPA. This observation is supported by preliminary evidence, indicating that the DGR rearrangements in scid cell lines have generated deletions internal to the construct (E.A. Hendrickson and D.T. Weaver, unpubl.). Thus, the scid defect associated with DNA rearrangement both persisted in cultured Ab-MLV-transformed cell lines and manifested the mutational effect on substrates introduced at multiple independent chromosomal sites. This experiment strongly suggested that the scid gene encodes a trans-acting factor that is a primary component of the lymphoid gene rearrangement mechanism.

Figure 7. The scid mutation encodes a trans-acting factor involved in Ig gene rearrangement. (Top) Established scid pre Bcell lines $8 D$ and $6 B$ were infected with $D G R$, a retrovirus that contains an Ig rearrangement cassette. Genomic DNA from eight independently established cell lines (numbered $1-11$ ) was isolated, digested with BamHI and HindIII, and subjected to Southern blot analysis, as described in Experimental procedures. Hybridization probe 1 (solid bar) was used to detect rearrangement events within the DGR rearrangement cassette. The positions of the unrearranged BamHI-HindIII fragment of DGR and the $V_{\mathrm{k}}-J_{\mathrm{a}}\left(J_{\mathrm{a}}\right)$ or $V_{\mathrm{k}}-J_{\mathrm{b}}\left(J_{b}\right)$ events are shown on the right. (Bottom) The DGR retroviral vector (from the left): the 5'-LTR, the $V_{\mathrm{k}}$ heptamer-nonamer sequences (solid triangle), the $B a m H I$ restriction site (B), the $V_{k}$ (open rectangle), the xanthine-guanine phosphoribosyl transferase gene-coding sequences (gpt, hatched rectangle), the $I_{a}$ and $J_{b}$ elements complete with their heptamer-nonamer sequences /open rectangle with solid triangle, respectively), the $S V 40$ promoter/enhancer sequences (SV40, stippled rectangle), the HindIII restriction site (H), the neomycin gene-coding sequences (neo, hatched rectangle), and the $3^{\prime}$-LTR. 


\section{Discussion}

We have studied Ig heavy-chain DNA rearrangement events that are defective in scid mouse pre-B-cell lines. scid Ig gene formation was arrested at the $D-I_{\mathrm{H}}$ rearrangement stage where $D$ elements of all three families $\left(D_{\mathrm{Q} 52}, D_{\mathrm{SP} 2}\right.$, and $\left.D_{\mathrm{FL} 16}\right)$ in the entire $D$ region were used, suggesting that the chromosomal selection of rearrangement sites was normal. However, extensive deletions usually occurred as a consequence of these rearrangement steps. By obtaining the DNA sequences of the breakpoint junctions of nine scid rearrangements, we determined that the joining reactions were defective in every case. No Ig heavy-chain gene products were capable of being synthesized as an outcome of these rearrangements. The structure of the novel breakpoints generated did not correspond to or align with any new or altered heptamer-nonamer recognition sequences in the unrearranged DNA.

\section{The scid gene product is a trans-acting factor of DNA rearrangement}

When Ab-MLV scid pre-B cell lines were infected with the DGR retrovirus containing an Ig rearrangement cassette, we consistently observed inappropriate deletions of the DGR DNA (Fig. 7). These data argue that the scid mutation is not restricted to the endogenous sites of lymphoid gene rearrangement because DGR integration most likely occurs randomly in the genome, and many independent events were observed. Also, we can conclude that the scid mutation is cell autonomous because the mutational effect persisted in isolated scid pre-B-cell lines. Every rearrangement, either of the endogenous Ig genes or of DGR, was defective, which strongly indicated that the SCID gene encodes a trans-acting factor that is directly involved in all normal DNA rearrangements, rather than any other lymphoid differentiation function. Therefore, we would predict that the appropriate differentiation of $s c i d$ pre-B cells to surface- $\mathrm{Ig}^{+} \mathrm{B}$ cells could occur solely by the introduction of normally rearranged Ig $\mu$ and $\kappa$ genes, circumventing the need for the endogenous gene rearrangement steps.

\section{scid rearrangements are stopped at the $\mathrm{D}-\mathrm{I}_{H}$ stage}

Our data demonstrate that the defective scid rearrangements are stopped at the $D-I_{\mathrm{H}}$ stage; the first stage of $\mathrm{Ig}$ heavy-chain gene rearrangement. No light-chain rearrangement or evidence for rearrangement of Ig $V_{\mathrm{H}}$ regions into the breakpoint junction fragments was observed. A $V_{\mathrm{H}} 81 \mathrm{X}$-specific hybridization probe (the $3^{\prime}$ most member of the $V_{\mathrm{H}}$ cluster) displayed the same intensity of hybridizing EcoRI fragments in all the scid cell lines (data not shown). Southern blot mapping of the junction fragments (Fig. 4) demonstrated that the $5^{\prime}$ region of the clones originated from the $D$ region. In two cases, the analysis could not distinguish between $D$ or $V$ incoming sequences, because the region of hybridization to the scid probe was deleted in all of the wild-type Ab-
MLV cell lines used in the assay. In both of these cases (3D26A-3 and 8B-8), the defective rearrangement occurred in the $D_{\mathrm{Q} 52}-J_{\mathrm{H}} E c o$ RI fragment (Fig. 6A); they were therefore aberrant $D-J_{\mathrm{H}}$ joining events. By comparison, in wild-type Ab-MLV pre-B cell lines derived from the bone marrow compartment, $\sim 80 \%$ of the Ig heavychain alleles have undergone $V D /_{\mathrm{H}}$ rearrangements (Alt et al. 1984). Wild-type Ab-MLV pre-B cells frequently contain $V D I_{\mathrm{H}}$ rearrangements on both alleles, or consist of one $V D I_{\mathrm{H}}$ functionally rearranged allele that produces $\mu$ protein and an allelically excluded second allele at the $D I_{\mathrm{H}}$ state. We and others have observed high frequencies of Ig heavy-chain alleles unrearranged or at the $D I_{\mathrm{H}}$ stage in Ab-MLV pre-B-cell lines from $\mu$ transgenic mice that are presumably due to allelic exclusion by the $\mu$ transgene (Rosconi and Kohler 1985; Weaver et al. 1985; Storb et al. 1986). Therefore, the scid data suggested the interesting possibility that accurate $D-J_{\mathrm{H}}$ rearrangement may be a necessary event for the continuation of the rearrangement and/or differentiation process. $D /_{\mathrm{H}}$ rearrangements have been shown to produce $D I_{H} \mu$ mRNA and $D \mu$ proteins in several normal Ab-MLV cell lines, and it has been postulated that production of this molecule may stimulate further gene rearrangement events (Reth and Alt 1984).

One property of the scid mutation is that it is somewhat leaky in that a small percentage of the animals can develop an oligoclonal B-cell population with age (Bosma et al. 1983). It is interesting that no joining event we characterized in the scid cell lines encoded production of a viable $D I \mu$ protein or a full-length $\mu(V D I)$ protein on the DNA sequence level. In addition, none of the 12 scid Ab-MLV cell lines isolated in this study produced either $D \mu$ or $\mu$ protein, as determined by metabolic labeling with $\left[{ }^{35} \mathrm{~S}\right]$ methionine, immunoprecipitation, and SDS-polyacrylamide gel electrophoresis (D. Weaver, unpubl.). In 8B-8, the breakpoint occurred within 3 nucleotides of the $3^{\prime}$ end of the $I_{\mathrm{H}}$ heptamer, which is similar to a normal rearrangement, but the other side of the breakpoint contained no Ig coding sequence. The nearest $D$ element still on the chromosome in the $8 \mathrm{~B}-8$ rearrangement is $\sim 19 \mathrm{~kb}, 5^{\prime}$ distant (Wood and Tonegawa 1983), and therefore no $D \mu$ or $\mu$ protein could be synthesized from it. Yet many of the scid rearrangements we have examined do not destroy all of the $J_{\mathrm{H}}$ and $D$ regions, making secondary rearrangement events possible that may accidentally append the appropriate sequences together. Presumably, there is a good selection in vivo for this type of low-frequency event, which may explain why the scid mutation has a leaky phenotype even though it has a severe recombination defect.

\section{Initiation of recombination by recognition of heptamer-nonamer sequences}

Wild-type lymphoid gene rearrangement events are directed by conserved heptamer-nonamer DNA sequences such that both the site of cleavage and rejoining of DNA strands occur flanking these diagnostic ele- 
ments. These heptamer-nonamer DNA sequences alone are sufficient to signal DNA rearrangement in exogenously added DNA (Akira et al. 1987). We investigated here whether this recognition phase of the rearrangement process was defective in scid pre-B cells. Our data support the notion that the normal heptamer-nonamer sequences are recognized in scid pre-B cells and that this recognition process in and of itself is not responsible for the scid deletions. An altered heptamernonamer motif was not found in the DNA regions flanking the breakpoints of the nine scid rearrangements, nor was there DNA homology between the flanking sequences themselves (Fig. 5). In addition, in the three cases where both the $D$ - and $J$-region DNA sequences flanking the breakpoint were determined, there was no homology observed between $D$ - and $J$-region DNA. If random recognition and cleavage steps occurred in the genomic EcoRI fragment to initiate recombination, then it would have been expected that some of the breakpoints would have been positioned in the region $5^{\prime}$ to the $J_{\mathbf{H}}$ cluster of the EcoRI fragment. However, the positions of nine scid breakpoints in the genomic $6.4-\mathrm{kb}$ EcoRI fragment all resided on the 3 'side of the $I_{\mathrm{Hl}}$ heptamer element (Fig. 2). Thus, the placement of the scid breakpoints is best explained not as representing the initial recognition or cleavage points in the rearrangement event, but as the consequence of variable deletions once the cleavage reaction has taken place. We currently are testing directly whether heptamer-nonamer recombination signals are required to initiate the aberrant rearrangements by introducing into scid pre-B cells recombinant retroviruses consisting of Ig rearrangement cassettes containing either wild-type heptamer sequences or heptamer mutations that destroy normal rearrangements (E. Hendrickson and D. Weaver, in prep.).

\section{Normal rearrangement is disrupted at the joining of strands in the scid mutation}

In one model for Ig recombination, the two gene elements $\left(D\right.$ and $\left.J_{\mathrm{H}}\right)$ are brought in close proximity, the heptamer-nonamer sequences of the $D$ and $J$ elements are recognized and cleaved, and a double-strand exonuclease digests either end of the DNA for a few nucleotides (Alt and Baltimore 1982). TdT may then add a few nucleotides to the $3^{\prime}$ strand of either end (generating $N$ regions). These $3^{\prime}$ overhanging ends may then be filled in by a DNA polymerase with a ligase activity finally covalently joining the strands. Of all of these enzymatic functions thought to be needed to generate a functional $D-I$ joint, we have evidence only for TdT activity. The identification of an $N$ region in clone $8 \mathrm{~B}-8$ suggested that this activity was not affected in scid mice. Our data are most consistent with the scid mutation either causing an increase in the activity of the exonuclease or a decrease in activity of the ligase function. If the rejoining of DNA is defective in scid mice by an impaired ligase function, the mutation might allow otherwise unrelated cellular nucleases the opportunity to attack the cleaved strands before they could be resealed.
It is also possible that the scid mutation encodes a general recombination or repair defect and may not be a lymphoid-specific function. For example, the SCID gene may have a parallel phenotype for Ig rearrangement as the RAD52 gene has for mating-type switching in Saccharomyces cerevisiae. Mating-type switching is initiated at a defined DNA position in the MAT locus by the $\mathrm{HO}$ endonuclease. In rad52 yeast strains during matingtype switching, the double strand breaks generated by the activity of $\mathrm{HO}$ protein at the normal site are lethal events and frequently give rise to variable deletions (Weiffenbach and Haber 1981; Weiffenbach et al. 1983). Although rad52 was characterized with a site-specific mating-type switching defect, it is believed to be a protein used in general recombination as well. By analogy, we are investigating this possibility for scid by inspecting the properties of scid pre-B cells after X-ray or methylmethane sulfonate treatments, both of which generate double-stranded breaks randomly in DNA.

\section{Experimental procedures}

\section{Cells and virus}

Bone marrow from a 10-week old homozygous scid mouse was removed and transformed with Ab-MLV ( $\mathrm{Pl} 60)$ by standard procedures (Rosenberg and Baltimore 1976; Weaver et al. 1985). Transformed colonies of pre-B cells were removed from soft agar plating and expanded in liquid media. Equivalent numbers of scid Ab-MLV cell lines were isolated, as compared to the standard yield from wild-type mouse bone marrow.

DGR virus was maintained in a $\psi 2$-producer cell line $(\psi$ DGR; Landau et al. 1987). scid pre-B cell lines $8 \mathrm{D}$ and $6 \mathrm{~B}$ $\left(1 \times 10^{6}\right.$ cells $)$ were infected by cocultivation with $\psi$-DGR cells $\left(5 \times 10^{6}\right.$ cells $)$ for $48 \mathrm{hr}$ prior to selection in media containing 2 $\mathrm{mg} / \mathrm{ml} \mathrm{G} 418$ for 3 weeks.

\section{Southern blots}

Genomic DNA was isolated for scid and wild-type Ab-MLV transformed pre-B cell lines $\left(1 \times 10^{8}\right.$ to $2 \times 10^{8}$ cells $)$ by treatment in $400 \mu \mathrm{g} / \mathrm{ml}$ of proteinase $\mathrm{K}, 1 \%$ SDS, $10 \mathrm{mM}$ Tris- $\mathrm{HCl}$ (pH 8.0), $50 \mathrm{mM}$ EDTA, and $100 \mathrm{mM} \mathrm{NaCl}$ for $>6 \mathrm{hr}$ at $37^{\circ} \mathrm{C}$. The samples were then extracted once with an equal volume of phenol, followed by one extraction with an equal volume of $\mathrm{CHCl}_{3}$. The DNA was then precipitated with an equal volume of isopropanol, spooled from solution, and resuspended at a concentration of $1 \mathrm{mg} / \mathrm{ml}$ in $10 \mathrm{~mm}$ Tris- $\mathrm{HCl}(\mathrm{pH} 8.0), 1 \mathrm{~mm}$ EDTA. Ten micrograms of genomic DNA was digested with restriction enzymes, fractionated on $0.8 \%$ agarose gels, prepared and transferred to nitrocellulose or Zetabind paper in $20 \times$ SSC, and baked in a vacuum oven (Maniatis et al. 1982). Prehybridization was conducted for $>4 \mathrm{hr}$ at $42^{\circ} \mathrm{C}$ in $50 \%$ formamide, $10 \times$ Denhardt's solution, $5 \times$ SSPE, $1 \%$ SDS, and 500 $\mu \mathrm{g} / \mathrm{ml}$ denatured herring sperm DNA. Hybridization probes were prepared from isolated restriction fragments, as specified in the figure legends, using mixed oligonucleotide primers (Boehringer Mannheim) and Klenow fragment DNA polymerase (Feinberg and Vogelstein 1984). Hybridizations were conducted for $36 \mathrm{hr}$ at $42^{\circ} \mathrm{C}$ in $50 \%$ formamide, $1 \times$ Denhardt's solution, $5 \times$ SSPE, $1 \%$ SDS, and $100 \mu \mathrm{g} / \mathrm{ml}$ denatured herring sperm DNA with the hybridization probes (sp. act. $10^{9} \mathrm{cpm} / \mu \mathrm{g}$ ). Blots were washed for $15 \mathrm{~min}$ at room temperature in $2 \times \mathrm{SSC}$, $0.1 \%$ SDS, followed by three consecutive washes for $30 \mathrm{~min}$ each at $68^{\circ} \mathrm{C}$ in $2 \times \mathrm{SSC}, 0.1 \%$ SDS. 


\section{Cloning of breakpoint fragments}

Forty micrograms of genomic DNA from nine Ab-MLV scid pre-B cell lines was digested with EcoRI and fractionated in $0.8 \%$ agarose gels. EcoRI-cleaved DNA size fractions containing the scid rearrangements were determined by a previous Southern blot (i.e., Fig. 1). One relevant size fraction per cell line was isolated from the preparative gel by silica glass powder binding in NaI (Vogelstein and Gillespie 1979). A phage $\lambda$ gt 10 library was then prepared from the size-selected DNA for each cell line (Maniatis et al. 1982). Phage libraries $\left(\sim 2 \times 10^{4}\right.$ to $10 \times 10^{4}$ recombinants per size selection library/ were screened using a 677 nucleotide-XbaI-EcoRI fragment ( $3^{\prime}$ probe, Fig. 1) hybridization probe (Maniatis et al. 1982). Phage DNA was isolated by standard miniprep procedures, and the EcoRI inserts were subcloned into pUC19 to generate the scid clones depicted in Figure 2.

\section{DNA sequencing of the $\mathrm{J}_{H}$ region breakpoint junctions}

The breakpoint junction of scid rearrangements in the $/_{\mathrm{H}}$ region were characterized by extensive restriction enzyme mapping and comparison to the known pattern for the germ-line 6.4-kb EcoRI fragment containing the $I_{\mathrm{H}}$ region. A small DNA restriction fragment spanning the breakpoint junction for each clone was radiolabeled at its $5^{\prime}$ termini by the sequential treatment with calf intestinal phosphatase and then polynucleotide $\mathrm{ki}$ nase (Boehringer Mannheim) in the presence of $\left[\gamma^{-32} \mathrm{P}\right] \mathrm{ATP}$. Radiolabeled DNA was then digested with a second restriction enzyme to yield two uniquely radiolabeled DNA fragments that were separated on a $1.0 \%$ agarose gel. Radiolabeled DNA was recovered from the gel by elution onto NA45 paper (Schleicher and Schuell). The radiolabeled fragments were subjected to DNA sequencing (Maxam and Gilbert 1980) and fractionated in $6 \%$ polyacrylamide $-8 \mathrm{M}$ urea sequencing gels using 0.2 to $1.0-\mathrm{mm}$ wedge-shaped spacers. Gels were fixed for $1 \mathrm{hr}$ in $10 \%$ glacial acetic acid, $12 \%$ methanol, vacuum-dried, and exposed for autoradiography.

\section{Isolation and DNA sequencing of D region breakpoint junctions and flanking $\mathrm{D}$ elements}

Hybridization probes were prepared from $0.15-\mathrm{kb}$ PvuII-OxaNI fragment of 3D26A-3 (see Fig. 6A) and from a 1.0-kb HindIII fragment of 7B5-3 (Fig. 6B). We screened a phage $\lambda$ EMBL3 genomic library containing partial $\mathrm{MboI}$ fragments of germ-line DNA from a BALB/c mouse (Winoto et al. 1985) independently with each hybridization probe (Maniatis et al. 1982). DNA from individual positive phage was isolated after a tertiary screen and then digested with the restriction enzyme EcoRI. The resulting DNA fragments were analyzed by Southern blotting as detailed above, and the positively hybridizing EcoRI fragments were subcloned into the EcoRI site of pUC19 to generate clones 614-4 (homologous to the 3D26A-3 probe) and 709T-1 (homologous to the 7B5-3 probel.

A 450-nucleotide PstI fragment spanning the breakpoint junction of 709T-1 DNA (Fig. 6B) was subcloned into the Pst I site of M13mpl9. Subclones of both orientations were sequenced according to Sanger et al. (1977) using the Sequenase sequencing kit (US Biochemicals). The 0.9-kb BamHI fragment of $709 \mathrm{~T}-1$, which contains the $D$ element, was subcloned into the BamHI site of pUC19. A series of plasmids containing overlapping, nested deletions into the insert region were generated using the Erase-a-Base system (Stratagene). Plasmid DNAs were purified from minipreps by an alkaline lysis procedure (Maniatis et al. 1982), and $3 \mu \mathrm{g}$ plasmid DNA was further purified with glass beads and NaI. Plasmid DNA $(1.5 \mu \mathrm{g})$ was denatured in $0.2 \mathrm{~N} \mathrm{NaOH}$ for $5 \mathrm{~min}, \mathrm{EtOH}$-precipitated in $0.33 \mathrm{M}$ $\mathrm{NH}_{4} \mathrm{OAc}$, resuspended in $\mathrm{H}_{2} \mathrm{O}$, and hybridized to either the Universal or Reverse DNA sequencing primers (US Biochemicals), and sequenced with the Sequenase kit. The breakpoint DNA sequence and the $D$ element for 614-4 were determined by subcloning the $2.4-\mathrm{kb} B a m H I$ fragment encompassing both of these elements (Fig. 6A) into the BamHI site of pUC19. As described above, a series of plasmids containing overlapping, nested deletions were generated and sequenced using the Erasea-Base and Sequenase protocols.

\section{Acknowledgments}

We are grateful to David Baltimore in whose laboratory these experiments were initiated. We thank Drs. Barbara Adams, Wolf Heyer, and Terry Orr-Weaver for critically reading the manuscript and for their helpful comments. We thank Rhonda Feinbaum for providing us with M13 DNA for DNA sequencing and Astar Winoto for the $\lambda E M B L 3$ library. This research was supported by National Institutes of Health (NIH) grant 1-R29GM39312-01 and the Whitaker Health Sciences Fund to D.T.W. E.A.H. was additionally supported by an NIH postdoctoral fellowship 1 F32 HD07034-01Al. D.G.S. was supported by fellowships from the Life and Health Insurance Medical Research Fund and the Whitaker Health Sciences Fund.

\section{References}

Akira, S., K. Okazaki, and H. Sakano. 1987. Two pairs of recombination signals are sufficient to cause immunoglobulin V-(D)-J joining. Science 238: 1134-1138.

Alt, F.W. and D. Baltimore. 1982. Joining of immunoglobulin heavy-chain gene segments: Implications from a chromosome with evidence of three $\mathrm{D}-\mathrm{I}_{\mathrm{H}}$ fusions. Proc. Natl. Acad. Sci. 79: 4118-4122.

Alt, F., T. Blackwell, R. DePinho, M. Reth, and G. Yancopoulos. 1986. Regulation of genome rearrangement events during lymphocyte differentiation. Immunol. Rev. 89: 5-30.

Alt, F., G. Yancopoulos, T. Blackwell, C. Wood, E. Thomas, M. Boss, R. Coffman, N. Rosenberg, S. Tonegawa, and D. Baltimore. 1984. Ordered rearrangement of immunoglobulin heavy-chain variable region segments. $E M B O J$. 3: 12091219.

Blackwell, T. and F. Alt. 1984. Site-specific recombination between immunoglobulin $D$ and $/_{\mathrm{H}}$ segments that were introduced into the genome of a murine pre-B cell line. Cell 37: 105-112.

Bosma, G.C., R.P. Custer, and M.J. Bosma. 1983. A severe combined immunodeficiency mutation in the mouse. Nature 301: $527-530$.

Davis, M. 1985. Molecular genetics of the T-cell receptor beta chain. Annu. Rev. Immunol. $3: 537-560$.

Desiderio, S.V., G.D. Yancopoulos, M. Paskind, E. Thomas, M.A. Boss, N. Landau, F.W. Alt, and D. Baltimore. 1984. Insertion of $\mathrm{N}$ regions into heavy-chain genes is correlated with expression of terminal deoxytransferase in B cells. $\mathrm{Na}$ ture 311: 752-755.

Dorschkind, K., G. Keller, R. Phillips, R. Miller, G. Bosma, M. $\mathrm{O}^{\prime}$ Toole, and M. Bosma. 1984. Functional status of cells from lymphoid and myeloid tissues in mice with severe combined immunodeficiency disease. I. Immunol. 132: $1804-1808$.

Early, P., H. Huang, M. Davis, K. Calame, and L. Hood. 1980. An immunoglobulin heavy-chain variable region gene is 
generated from three segments of DNA: $\mathrm{V}_{\mathrm{H}}, \mathrm{D}$, and $\mathrm{J}_{\mathrm{H}}$. Cell 19: $981-992$.

Feinberg, A. and B. Vogelstein. 1984. A technique for radiolabeling DNA restriction endonuclease fragments to high specific activity. Anal. Biochem. 137: 266-267.

Kronenberg, M., G. Siu, L. Hood, and N. Shastri. 1986. The molecular genetics of the T-cell antigen receptor and T-cell antigen recognition. Annu. Rev. Immunol. 4: 529-591.

Kurosawa, Y. and S. Tonegawa. 1982. Organization, structure and assembly of immunoglobulin heavy-chain diversity DNA segments. J. Exp. Med. 155: 201-218.

Landau, N., D. Schatz, M. Rosa, and D. Baltimore. 1987. Increased frequency of $N$-region insertion in a murine pre-Bcell line infected with a terminal deoxynucleotidyl transferase retroviral expression vector. Mol. Cell. Biol. 7: 32373243.

Lewis, S., A. Gifford, and D. Baltimore. 1984. Joining of $V_{k}$ to $J_{k}$ gene segments in a retroviral vector introduced into lymphoid cells. Nature 308: 425-428.

- 1985. DNA elements are asymmetrically joined during site-specific recombination of kappa immunoglobulin genes. Science 228: 677-685.

Lieber, M., J. Hesse, K. Mizuuchi, and M. Gellert. 1987. Developmental stage specificity of the lymphoid V(D)J recombination activity. Genes Dev. 1: 751-761.

Maniatis, T., E.F. Fritsch, and J. Sambrook. 1982. Molecular cloning: A laboratory manual. Cold Spring Harbor Laboratory, Cold Spring Harbor, New York.

Maxam, A.M. and W. Gilbert. 1980. Sequencing end-labeled DNA with base-specific chemical cleavages. Methods Enzymol. 65: 499-560.

Reth, M. and F. Alt. 1984. Novel immunoglobulin heavy-chains are produced from $D J_{H}$ gene segment rearrangements in lymphoid cells. Nature 312: 418-423.

Rosconi, S. and G. Kohler. 1985. Transmission and expression of a specific pair of rearranged immunoglobulin $\mu$ and $K$ genes in a transgenic mouse line. Nature 314: 330-333.

Rosenberg, N. and D. Baltimore. 1976. A quantitative assay for transformation of bone marrow cells by Abelson murine leukemia virus. I. Exp. Med. 143:1453-1463.

Sakano, H., Y. Kurosawa, M. Weigert, and S. Tonegawa. 1981. Identification and nucleotide sequence of a diversity DNA segment (D) of immunoglobulin heavy-chain genes. Nature 290: $562-565$.

Sanger, F., S. Nicklen, and A.R. Coulson. 1977. DNA sequencing with chain-terminating inhibitors. Proc. Natl. Acad. Sci. 74: 5463-5467.

Schatz, D. and D. Baltimore. 1988. Stable expression of immunoglobulin gene $\mathrm{V}(\mathrm{D}) \mathrm{J}$ recombinase activity by gene transfer into 3T3 fibroblasts. Cell 53: 107-115.

Schuler, W., I.J. Weiler, A. Schuler, R.A. Phillips, N. Rosenberg, T.W. Mak, J.F. Kearney, R.P. Perry, and M.J. Bosma. 1986. Rearrangement of antigen receptor genes is defective in mice with severe combined immune deficiency. Cell 46: 963-972.

Storb, U., C. Pinkert, B. Arp, P. Engler, K. Gollahon, J. Manz, W. Brady, and R. Brinster. 1986. Transgenic mice with $\mu$ and $\kappa$ genes encoding antiphosphorylcholine antibodies. I. Exp. Med. 164: 627-641.

Tonegawa, S. 1983. Somatic generation of antibody diversity. Nature 302: 575-581.

Vogelstein, B. and R. Gillespie. 1979. Preparative and analytical purification of DNA from agarose. Proc. Natl. Acad. Sci. 76: 615-619.

Weaver, D., F. Costantini, T. Imanishi-Kari, and D. Baltimore. 1985. A transgenic immunoglobulin mu gene prevents rear- rangement of endogenous genes. Cell 42: 117-127.

Weiffenbach, B. and J. Haber. 1981. Homothallic mating type switching generates lethal chromosome breaks in rad52 strains of Sacchromyces cerevisiae. Mol. Cell. Biol. 1: 522534.

Weiffenbach, B., D. Rogers, J. Haber, M. Zoller, D. Russell, and M. Smith. 1983. Deletions and single base pair changes in the yeast mating type locus that prevent homothallic mating type conversion. Proc. Natl. Acad. Sci. 80: 34013405.

Winoto, A., S. Mjolsness, and L. Hood. 1985. Genomic organization of the genes encoding the mouse T-cell receptor $\alpha$ chain: $18 \mathrm{~J} \alpha$ gene segments map over 60 kilobases of DNA. Nature 316: 832-836.

Wood, C. and S. Tonegawa. 1983. Diversity and joining segments of mouse immunoglobulin chain genes are closely linked and in the same orientation: Implications for the joining mechanism. Proc. Nat1. Acad. Sci. 80: 3030-3034.

Yancopoulos, G., T. Blackwell, H. Suh, L. Hood, and F. Alt. 1986. Introduced $T$ cell receptor variable region gene segments in pre-B cells: Evidence that $B$ and $T$ cells use a common recombinase. Cell 44: 251-259. 


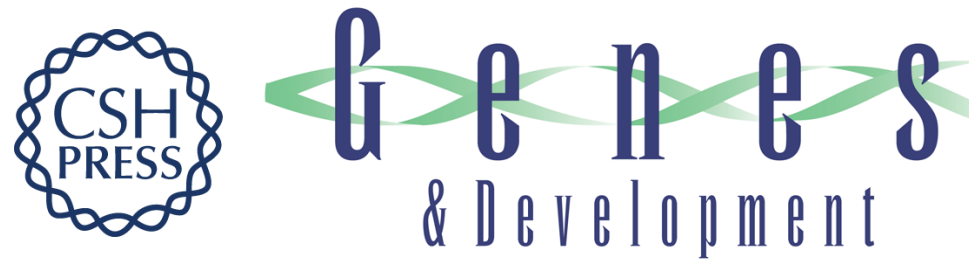

\section{The scid gene encodes a trans-acting factor that mediates the rejoining event of Ig gene rearrangement.}

E A Hendrickson, D G Schatz and D T Weaver

Genes Dev. 1988, 2:

Access the most recent version at doi:10.1101/gad.2.7.817

References This article cites 34 articles, 13 of which can be accessed free at:

http://genesdev.cshlp.org/content/2/7/817.full.html\#ref-list-1

License

Email Alerting Receive free email alerts when new articles cite this article - sign up in the box at the top Service right corner of the article or click here.

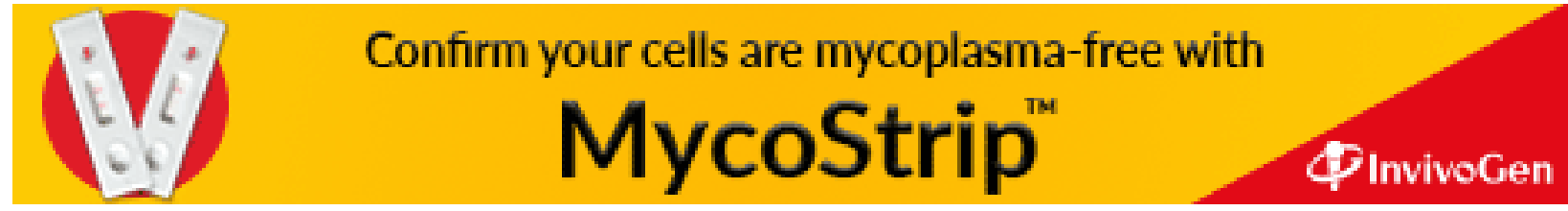

